\title{
HYPERBILIRUBINAEMIA IN ACUTE APPENDICITIS AND ITS ROLE IN PREDICTING COMPLICATIONS, PARTICULARLY APPENDICULAR PERFORATION
}

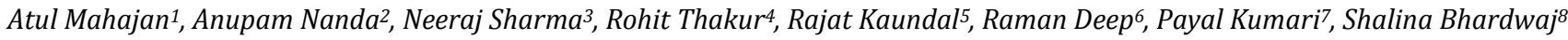

1 Professor, Department of Surgery, Dr. RPGMC, Tanda, Kangra, H. P.

${ }^{2}$ Senior Resident, Department of Surgery, Dr. RPGMC, Tanda, Kangra, H. P.

3 Junior Resident, Department of Surgery, Dr. RPGMC, Tanda, Kangra, H. P.

4Junior Resident, Department of Surgery, Dr. RPGMC, Tanda, Kangra, H. P.

5Intern, Department of Surgery, Dr. RPGMC, Tanda, Kangra, H. P.

${ }^{6}$ Intern, Department of Surgery, Dr. RPGMC, Tanda, Kangra, H. P.

7Intern, Department of Surgery, Dr. RPGMC, Tanda, Kangra, H. P.

8Intern, Department of Surgery, Dr. RPGMC, Tanda, Kangra, H. P.

ABSTRACT

\section{BACKGROUND}

Appendicitis is a disease of young adults with $40 \%$ of cases occurring in patients between the ages of 10 and 29 years. Appendectomy is the most commonly performed urgent abdominal surgery. This study aims at revealing hyperbilirubinaemia as a laboratory marker for diagnosing the severity of acute appendicitis based on correlation between hyperbilirubinaemia and intra-operative findings in patients undergoing emergency appendectomy for acute appendicitis.

\section{MATERIALS AND METHODS}

This descriptive study reviewed the correlation of hyperbilirubinaemia and acute appendicitis and its complications among the 237 patients who had undergone open or laparoscopic appendectomy (after excluding patients with other causes of hyperbilirubinaemia) in our institution from January 2015 to July 2017. A retrospective chart review of medical records, lab investigations and intraoperative findings were recorded and the data was analysed.

\section{RESULTS}

Among 237 patients who had undergone emergency open or laparoscopic appendectomy during this interval, hyperbilirubinaemia was found in 89 patients (37.55\%). Among these 72 patients $(80.90 \%)$ had perforated or gangrenous appendix, whereas appendix was found to be inflamed in 17 patients (19.10\%). Normal levels of serum bilirubin was found in 148 patients (62.44\%), out of which 32 patients (21.62\%) had perforated appendix and remaining 116 patients $(78.38 \%)$ had inflamed appendix.

\section{CONCLUSION}

In our study hyperbilirubinaemia was found in $12.78 \%$ of patients with acute appendicitis without any complication, whereas hyperbilirubinaemia was seen in $69.23 \%$ of patients with acute appendicitis with perforation/gangrene. Thus, serum bilirubin can be used as an adjunct laboratory tool for diagnosing the severity of acute appendicitis.

\section{KEYWORDS}

Hyperbilirubinaemia, Acute Appendicitis.

HOW TO CITE THIS ARTICLE: Mahajan A, Nanda A, Sharma N, et al. Hyperbilirubinaemia in acute appendicitis and its role in predicting complications, particularly appendicular perforation. J. Evolution Med. Dent. Sci. 2017;6(76):5435-5438, DOI: 10.14260/Jemds/2017/1179

\section{BACKGROUND}

Appendicitis is a disease of young adults with $40 \%$ of cases occurring in patients between the ages of 10 to 29 years. ${ }^{1}$ Appendectomy is the most commonly performed urgent abdominal surgery. ${ }^{2}$ Although, most patients with acute appendicitis can be easily diagnosed, in some cases signs and symptoms are variable and a firm diagnosis can be difficult. Delay in surgery in these cases due to any reason- delayed presentation or mistaken judgement leads to dreaded complications like gangrenous changes and perforation.

Financial or Other, Competing Interest: None.

Submission 08-08-2017, Peer Review 08-09-2017,

Acceptance 13-09-2017, Published 21-09-2017.

Corresponding Author:

Dr. Atul Mahajan,

Anand Bhawan, Dane Road, Dharamshala Dist,

Kangra-176215, H. P.

E-mail: dratulmahajan@yahoo.co.in

DOI: $10.14260 /$ jemds/2017/1179
The incidence of perforated appendix in adults has been reported from $13 \%-37 \%{ }^{3}$ A timelier and more accurate diagnosis has been attempted by the use of additional laboratory tests, ${ }^{4-9}$ scoring systems, ${ }^{10-13}$ sonography,14,15 computed tomography, 16,17 but none of these methods stand alone as they all come in support of and are secondary to a primary clinical diagnosis. Increasing use of CT scanning in acute appendicitis increases the cost of care, stay time in the emergency department and delays the time for surgery. ${ }^{18}$

The association between elevated serum bilirubin levels and infectious diseases has been noted in certain studies. Studies conducted by Estrada et al ${ }^{19}$ and others ${ }^{20,21}$ demonstrate a nearly three-fold risk of perforated appendicitis in patients with total serum bilirubin levels more than $1 \mathrm{mg} / \mathrm{dL}$.

Physical examinations and laboratory tests are still acknowledged to be of utmost importance in diagnosing acute appendicitis. ${ }^{22}$ We tried to find key laboratory tests that would allow us to anticipate the severity of acute appendicitis. This 
study is done to evaluate the association between hyperbilirubinaemia in cases of acute appendicitis and its complications. The establishment of a possible role of hyperbilirubinaemia as a predictor of perforated/gangrenous appendicitis has been stressed, so that serum bilirubin levels upon admission can be used in conjunction with other diagnostic tests to help determine the severity of acute appendicitis and aid in proper clinical management.

\section{Objectives}

To study the co-relation between serum total bilirubin and acute appendicitis, particularly perforated/gangrenous appendicitis and to know whether hyperbilirubinaemia can be used as a marker for diagnosing the severity of acute appendicitis, particularly appendicular perforation or gangrene in preoperative period.

\section{MATERIALS AND METHODS}

\section{Study Design}

This is a descriptive study based on data collected from the case sheets of patients who had undergone emergency appendectomy for acute appendicitis during January 2015 to July 2017 in the Department of Surgery, Dr. RPGMC Tanda (HP) after observing inclusion and exclusion criteria.

\section{Inclusion Criteria}

All patients irrespective of age who had undergone emergency open or laparoscopic appendectomy for acute appendicitis based on clinical examination during this period.

\section{Exclusion Criteria}

All patients with documented history of jaundice/liver disease, chronic alcoholism, haemolytic disease, biliary tract disease, HBsAg positive, hepatobiliary tract malignancy were excluded from the study.

The patients were divided into two groups. Group ' $A$ ' includes those patients with acute appendicitis in whom intraoperatively appendix was found to be inflamed and turgid but not perforated and Group 'B' of patients with intra-operatively perforated or gangrenous appendicitis.

The results were analysed by chi-square test using Epi Info Software version 7.1.3.0.

\section{RESULTS}

A total of 239 emergency appendectomies were performed during this interval in our institution. Out of these, one patient of acute appendicitis with cholelithiasis (USG finding) and the other one, acute appendicitis with ileal perforation (intra-op finding) were excluded from this study. Rest 237 patients, Males $=144(60.76 \%)$, Females $=93(39.24 \%)$ who had undergone emergency appendectomy with a clinical diagnosis of acute appendicitis or appendiceal perforation were included in the study.

1. Out of 237 emergency appendectomies done during this interval, 133 patients (56.12\%) had inflamed and turgid appendix (non-perforated/gangrenous), i.e. Group 'A' and 104 patients $(43.88 \%)$ had perforated appendix intraoperatively, i.e. Group 'B' (Table 1).

\begin{tabular}{|c|c|c|}
\hline Intra-Op Appendix & Number & \%age \\
\hline $\begin{array}{c}\text { Inflamed/turgid/oedematous } \\
\text { (non-perforated/gangrenous) (Group 'A') }\end{array}$ & 133 & 56.12 \\
\hline Perforated/+Gangrenous (Group 'B') & 104 & 43.88 \\
\hline \multicolumn{2}{|c|}{ Table 1 } & \\
\hline
\end{tabular}

2. Mean total serum bilirubin of 237 patients (Group 'A' + Group 'B') was $1.04 \mathrm{mg} / \mathrm{dL}$ (with an SD of 0.8 ), which was above the normal range $(\leq 1.0 \mathrm{mg} / \mathrm{dL})$. In Group ' $\mathrm{A}$ ' out of total of 133 patients, the mean of total serum bilirubin was $0.69 \mathrm{mg} / \mathrm{dL}$ (with an SD of 0.58), which was below the normal range $(\leq 1.0 \mathrm{mg} / \mathrm{dL})$. In Group ' $\mathrm{B}$ ' the mean of total serum bilirubin was $1.48 \mathrm{mg} / \mathrm{dL}$ (with an SD of 0.82 ), which was above the normal range $(\leq 1.0 \mathrm{mg} / \mathrm{dL})$.

\begin{tabular}{|c|c|c|c|}
\hline Parameters & $\begin{array}{c}\text { Total Patients } \\
\text { with Acute } \\
\text { Appendicitis } \\
\text { (Group A + } \\
\text { Group B) } \\
\text { Mean } \pm \text { SD }\end{array}$ & $\begin{array}{c}\text { Group A } \\
\text { Mean } \pm \text { SD }\end{array}$ & $\begin{array}{c}\text { Group B } \\
\text { Mean } \pm \text { SD }\end{array}$ \\
\hline $\begin{array}{c}\text { Total bilirubin } \\
\text { (mg/dL) }\end{array}$ & $1.04 \pm 0.80 \mathrm{mg} / \mathrm{dL}$ & $0.69 \pm 0.58$ & $1.48 \pm 0.82$ \\
\hline \multicolumn{3}{|c|}{ Table 2. Serum Bilirubin Levels } \\
\hline
\end{tabular}

3. Out of total of 237 patients (Group 'A' + Group 'B') who had undergone emergency appendectomy, 148 patients $(62.44 \%)$ had normal bilirubin levels $(\leq 1.0 \mathrm{mg} / \mathrm{dL})$, while 89 patients $(37.56 \%)$ had raised bilirubin levels $(>1.0$ $\mathrm{mg} / \mathrm{dL}$ ). In Group 'A' out of total of 133 patients, 116 $(87.22 \%)$ patients had normal bilirubin $(\leq 1.0 \mathrm{mg} / \mathrm{dL})$ levels, whereas $17(12.78 \%)$ patients had raised bilirubin levels $(>1.0 \mathrm{mg} / \mathrm{dL})$. In group 'B' out of total of 104 patients, $32(30.77 \%)$ patients had normal bilirubin levels ( $\leq 1.0 \mathrm{mg} / \mathrm{dL}$ ), whereas $72(69.23 \%)$ patients had raised bilirubin levels (> $1.0 \mathrm{mg} / \mathrm{dL})$.

4. Of 133 patients in Group 'A,' i.e. acute appendicitis without any perforation/gangrene, only 17 patients $(12.78 \%)$ had raised serum bilirubin levels $(>1.0 \mathrm{mg} / \mathrm{dL})$ preoperatively, while the remaining 116 patients $(87.22 \%)$ had normal serum bilirubin levels $(\leq 1.0$ $\mathrm{mg} / \mathrm{dL}$ ). Out of 104 patients in Group 'B' in whom intraoperatively appendix was found to be perforated/gangrenous, 72 patients $(69.23 \%)$ had raised serum bilirubin levels ( $>1.0 \mathrm{mg} / \mathrm{dL}$ ) preoperatively, while the remaining 32 patients (30.77\%) had normal serum bilirubin levels $(\leq 1.0 \mathrm{mg} / \mathrm{dL})$.

These results were analysed using chi-square tests Epi Info version 7.1.3.0 with a " $\mathrm{p}$ " value $<0.001$, which is highly significant (Table 3).

\begin{tabular}{|c|c|c|c|c|c|}
\hline \multirow{4}{*}{$\begin{array}{c}\text { Pre- } \\
\text { operative } \\
\text { Serum } \\
\text { Bilirubin } \\
(\mathrm{mg} / \mathrm{dL})\end{array}$} & \multicolumn{4}{|c|}{ Final Diagnosis $(n=237)$} & \multirow{4}{*}{ P-value } \\
\hline & \multirow{2}{*}{\multicolumn{2}{|c|}{$\begin{array}{c}\text { Acute } \\
\text { Appendicitis } \\
\text { without } \\
\text { Perforation/ } \\
\text { Gangrene } \\
\text { (Group 'A') } \\
\text { (n=133) }\end{array}$}} & \multicolumn{2}{|c|}{$\begin{array}{c}\text { Acute } \\
\text { Appendicitis with } \\
\text { Perforation/ } \\
\text { Gangrene } \\
\text { (Group 'B') }\end{array}$} & \\
\hline & & & & 4) & \\
\hline & No. & $\%$ & No. & $\%$ & \\
\hline$>1.0$ & 017 & 12.78 & 072 & 69.23 & \multirow{3}{*}{$<0.001$} \\
\hline$\leq 1.0$ & 116 & 87.22 & 032 & 30.77 & \\
\hline Total & 133 & 100.00 & 104 & 100.00 & \\
\hline \multicolumn{6}{|c|}{$\begin{array}{l}\text { Table 3. Correlation of Acute Appendicitis and Appendiceal } \\
\text { Perforation with Total Serum Bilirubin Levels }\end{array}$} \\
\hline
\end{tabular}




\begin{tabular}{|c|c|c|c|c|c|}
\hline \multirow{4}{*}{$\begin{array}{l}\text { Pre- } \\
\text { Operative } \\
\text { Serum } \\
\text { Bilirubin } \\
\text { (mg/dl) }\end{array}$} & \multicolumn{4}{|c|}{ Final Diagnosis $(n=237)$} & \\
\hline & \multirow{2}{*}{\multicolumn{2}{|c|}{$\begin{array}{c}\text { Acute } \\
\text { Appendicitis } \\
\text { without } \\
\text { Perforation/ } \\
\text { Gangrene } \\
\text { (Group 'A') } \\
(n=133)\end{array}$}} & \multicolumn{2}{|c|}{$\begin{array}{c}\text { Acute } \\
\text { Appendicitis } \\
\text { with Perforation } \\
\text { /Gangrene } \\
\text { (Group 'B') }\end{array}$} & \\
\hline & & & & 04) & n-value \\
\hline & No. & $\%$ & No. & $\%$ & p-value \\
\hline$>1.0$ & 017 & 12.78 & 072 & 69.23 & \\
\hline$\leq 1.0$ & 116 & 87.22 & 032 & 30.77 & $<0.001$ \\
\hline Total & 133 & 100.00 & 104 & 100.00 & \\
\hline
\end{tabular}

\section{DISCUSSION}

The incidence of acute appendicitis varies from 7 to 22 per 10,000 population. ${ }^{23,24}$ Appendicitis is most frequently seen in young patients in their $2^{\text {nd }}$ to $4^{\text {th }}$ decade of life with a mean age of 31.3 years and a median age of 22 years. ${ }^{25}$ Obstruction to the lumen is believed to be the major cause of acute appendicitis. Fecaliths are the usual cause of obstruction and less common causes are hypertrophy of lymphoid tissue, tumours, intestinal parasites, non-perforated acute appendicitis can be cured by appendectomy without any long recovery period, whereas delay in diagnosis and surgery in these patients can lead to dreaded complication like perforation and gangrene.

In our study, out of 237 patients increased serum bilirubin levels (> $1.0 \mathrm{mg} / \mathrm{dL}$ ) were observed in 89 patients $(37.55 \%)$, while remaining 148 patients (62.45\%) had normal levels $(\leq$ $1.0 \mathrm{mg} / \mathrm{dL}$ ). Out of 89 patients with hyperbilirubinaemia, 72 patients $(80.9 \%)$ had perforated appendix and remaining 12 patients $(19.1 \%)$ had uncomplicated appendicitis.

When the results were analysed taking into consideration the pre-operative serum bilirubin levels in either group ' $p$ ' value of total serum bilirubin was calculated to be $<0.001$, which was highly significant. Since these tests were done prior to the surgery, it is unlikely that liver injury because of anaesthetic drugs was the cause of liver injury. The most likely cause of rise in serum total bilirubin is circulating endotoxinaemia.

A study conducted by Utili et al ${ }^{26,27,28}$ on rats also shows the similar results. The study conducted by Sisson et $\mathrm{al}^{29}$ demonstrates that gangrenous or perforated appendicitis is associated with progressive bacterial invasion into the muscularis propria of appendix, which is facilitated by bacterial cytotoxins. Study conducted by Estrada et al ${ }^{20}$ had found significantly higher peritoneal culture in patients with gangrenous/perforated appendicitis.

Studies conducted by Estrada et al $^{19}$ and others 20,21 demonstrate a nearly three-fold risk of perforated appendicitis in patients with total serum bilirubin levels more than $1 \mathrm{mg} / \mathrm{dL}$.

In the study conducted by Dr. A. Q. Khan ${ }^{30}$ et al, Sensitivity and Specificity of bilirubin in predicting appendicular perforation $88 \%$ and $80 \%$ respectively; similarly, positive predictive value and negative predictive value of bilirubin in predicting appendicular perforation $81.48 \%$ and $86.96 \%$ respectively. In the study done by Emmanuel ${ }^{31}$ et al found out specificity of hyperbilirubinaemia for appendicular perforation was found to be $70 \%$.

Several mechanisms have been described explaining serum bilirubin elevations in systemic infections. The haemolysis produced by certain bacteria including E. coli, produces an increase in indirect and total bilirubin. Also, some endotoxins released in the peripheral blood stream are responsible for impeding the liver's mechanisms for bilirubin uptake and canalicular excretion. Endotoxin produce cholestasis by damaging biliary salt transport through cytokine-mediated mechanisms. Elevated serum bilirubin levels in acute appendicitis can either appear as a result of bacteraemia or endotoxinaemia, both possible in the catarrhal and phlegmonous forms as well as in the gangrenous or perforated ones. Before 1950, about $0.4 \%$ cases of acute appendicitis were complicated with superior mesenteric vein thrombophlebitis and now this complication has become very rare in the present era due to antibiotics and early surgical intervention.

\section{CONCLUSION}

Elevation in total serum bilirubin levels can be used as a criterion to diagnose acute appendicitis with perforation/ gangrene. Measurement of total serum bilirubin levels is simple, cheap and available in every laboratory and can be added to the routine investigation list of clinically suspected cases of acute appendicitis for early identification of its complications. In our study, out of 237 patients with acute appendicitis, hyperbilirubinaemia was found in $69.23 \%$ of patients with perforated/gangrenous appendicitis against $12.78 \%$ of patients with acute appendicitis without any complication.

\section{REFERENCES}

[1] Jaffe BM, Berger DH. The appendix. In: Brunicardi FC (edr). Schwartz's principles of surgery. $9^{\text {th }}$ edn. Mc Graw Hill 2010:1073-89.

[2] O' Connel PR. The vermiform appendix. In: Williams NS, Bulstrode CJK, O' Connel, (edr). Bailey and love's - short practice of surgery. $25^{\text {th }}$ edn. London: Arnald 2008:1204-8.

[3] Ghimire P, Thapa P, Yogi N, et al. Role of serum bilirubin as a marker of acute gangrenous appendicitis. Nepal Journal of Medical sciences 2012;1(2):89-92.

[4] Oruc MT, Kulah B, Ozozan 0, et al. The value of 5hydroxy indole acetic acid measurement in spot urine in diagnosis of acute appendicitis. East African Med J 2004;81:40-1.

[5] Taha AS, Grant V, Kelly RW. Urinalysis for interleukin-8 in the non-invasive diagnosis of acute and chronic inflammatory diseases. Postgrad Med J 2003;79(929):159-63.

[6] Hallan S, Asberg A. The accuracy of C-reactive protein in diagnosing acute appendicitis- a meta-analysis. Scan J Clin Lab Invest 1997;57(5):373-80.

[7] Goodwin AT, Swift RI, Bartlett MJ, et al. Can serum interleukin-6 levels predict the outcome of patients with right iliac fossa pain? Ann R Coll Surg Engl 1997;79(2):130-3. 
[8] Vermeulen B, Morabia A, Unger PF. Influence of white cell count on surgical decision making in patients with abdominal pain in the right lower quadrant. Eur J Surg 1995;161(7):483-6.

[9] Albu E, Miller BM, Choi Y, et al. Diagnostic value of Creactive protein in acute appendicitis. Dis Colon Rectum 1994;37(1):49-51.

[10] Christian F, Christian GP. A simple scoring system to reduce the negative appendicectomy rate. Ann $\mathrm{R}$ Coll Surg Engl 1992;74(4):281-5.

[11] Alvarado A. A practical score for early diagnosis of acute appendicitis. Ann Emerg Med 1986;15(5):55764.

[12] Ohmann C, Franke C, Yang Q. Clinical benefit of a diagnostic score for appendicitis: results of a prospective interventional study. German study group of acute abdominal pain. Arch Surg 1999;134(9):993-6.

[13] Zielke A, Sitter H, Rampp T, et al. Can diagnostic scoring systems help decision making in primary care of patients with suspected acute appendicitis? Zeilke Dtsch Med Wochenschr 1999;124(18):545-50.

[14] Douglas CD, Macphrenson NE, Davidson PM, et al. Randomised controlled trial of ultrasonography in diagnosis of acute appendicitis, incorporating the alvarado score. BMJ 2000;321:919-22.

[15] Rettenbacher T, Hollerweger A, Gritzmann N, et al. Appendicitis: should diagnostic imaging be performed if the clinical presentation is highly suggestive of the disease? Gastroenterology 2002;123(4):992-8.

[16] Walker S, Haun W, Clark J, et al. The value of limited computed tomography with rectal contrast in the diagnosis of acute appendicitis. Am J Surg 2000;180(6):450-5.

[17] Hong JJ, Cohn SM, Ekeh AP, et al. A prospective randomized study of clinical assessment versus computed tomography for the diagnosis of acute appendicitis. Surg Infect (Larchmt) 2003;4(3):231-9.

[18] Pritchett CV, Levinsky NC, Ha YP, et al. Management of acute appendicitis: the impact of CT scanning on the bottom line. J Am Coll Surg 2010;210(5):699-705.

[19] Estrada JJ, Petrosyan M, Barnhart J, et al. Hyperbilirubinemia in appendicitis: a new predictor of perforation. J Gastrointest Surg 2007;11(6):714-8.
[20] Bennion RS, Baron EJ, Thompson JE, et al. The bacteriology of gangrenous and perforated appendicitis- revisited. Ann Surg 1990;211(2):165-71.

[21] Bennion RS, Thompson JE, Baron EJ, et al. Gangrenous and perforated appendicitis with peritonitis: treatment and bacteriology. Clin Ther 1990;12 Suppl C:31-44.

[22] Kalliakmanis V, Pikoulis E, Karavokyros IG, et al. Acute appendicitis: the reliability of diagnosis by clinical assessment alone. Scand J Surg 2005;94(3):201-6.

[23] Lee JH, Park YS, Choi JS. The epidemiology of appendicitis and appendectomy in South Korea: national registry data. J Epidemiol 2010;20(2):97-105.

[24] Buckius MT, McGrath B, Monk J, et al. Changing epidemiology of acute appendicitis in the United States: study period 1993-2008. J Surg Res 2012;175(2):18590.

[25] Ajmani ML, Ajmani K. The positon, length and arterial supply of vermiform appendix. Anat Anz 1983;153(4):369-74.

[26] Utili R, Abernathy CO, Zimmerman HJ. Cholestatic effects of escherichia coli endotoxin on the isolated perfused rat liver. Gastroenterology 1976;70(2):24853.

[27] Utili R, Abernathy CO, Zimmerman HJ. Studies on the effects of C. coli endotoxin on canalicular bile formation in the isolated perfused rat liver. J Lab Clin Med 1977;89(3):471-82.

[28] Utili R, Abernathy CO, Zimmerman HJ. Endotoxin effects on the liver. Life Sci 1977;20(4):553-68.

[29] Sisson RS, Ahlvin RC, Harlow MC. Superficial mucosal ulceration and the pathogenesis of acute appendicitis. Am J Surg 1971;122(3):378-80.

[30] Khan AQ, Patil A, Pawar P. Role of hyperbilirubinemia as a diagnostic predictor of appendicular perforation. International Journal of Science and Research (IJSR) 2014;3(12):1026-28.

[31] Emmanuel A, Murchan P, Wilson I, et al. The value of hyperbilirubinaemia in the diagnosis of acute appendicitis. Ann R Coll Surg Engl 2011;93(3):213-7. 